\title{
The Influence of Firm Performance, Firm Size and Debt Monitoring on Firm Value: The Moderating Role of Earnings Management
}

\author{
Rina Br Bukit \\ Faculty of Economic and Business, \\ Universitas Sumatera Utara, \\ Padang Bulan, 20155, Medan, \\ Indonesia \\ rina.bukit @gmail.com; \\ rina.bukit@usu.ac.id
}

\author{
Fahmi N Nasution \\ Faculty of Economic and Business, \\ Universitas Sumatera Utara, \\ Padang Bulan, 20155, Medan, \\ Indonesia
}

\author{
Paham Ginting \\ Faculty of Economic and Business, \\ Universitas Sumatera Utara, \\ Padang Bulan, 20155, Medan, \\ Indonesia
}

\author{
Nurzaimah \\ Faculty of Economic and Business, Universitas \\ Sumatera Utara, Padang Bulan, 20155, Medan, \\ Indonesia
}

\author{
Phou Sambath \\ Faculty of Social Science and Humanities \\ Royal University of Phnom Penh, \\ Phnom Penh, Cambodia
}

\begin{abstract}
This study aims to test if firm performance, firm size and debt monitoring can increase the firm value in two different conditions: high earnings management and low earnings management. Sample of manufacturing companies is taken from the list of Indonesia Stock Exchange during the period of 20142016. Using multiple regression analysis, discloses that: in high earnings management practices, the company's value may decrease, although the company reported good performance. This study also finds that earnings management practices moderates the positive association between firm size and firm value. However, debt monitoring cannot improve firm value, in both situations: High vs. Low earnings manipulation. Monitoring system need to be intensified especially for companies with the above characteristics.
\end{abstract}

Keywords-Firm Value; Firm Performance; Firm Size; Debt Monitoring; Earnings Management

\section{INTRODUCTION}

A company was established with the aim of increasing the value of the company so as to provide prosperity for the owners or shareholders. The value of a company is important because it deals with the welfare of its shareholders. Firm value can be illustrated from the stock price level that indicates the future prospects of the company. In addition, some researchers also illustrate the value of companies using Tobin Q. Tobin's Q is calculated by comparing the ratio of the market value of the company's stock to the book value of the company's equity. This ratio is a valuable concept because it shows the current financial market estimates of the return value of each dollar of incremental investment. The reason for the use of Tobin's Q in this study is that $\mathrm{Q}$ ratios are a more rigorous measure of how effectively management makes use of economic resources in its power [1].
Research on firm value is still interesting since the information concerning company value is very important for stakeholders. Previous researches show that several factors influence firm value such as firm performance [2], firm size [3], and debt monitoring [4]. First, firm performance is often described as firm efficiency, financial stability or financial health. The information of firm performance is important for shareholders, which is related to their interests and welfare. Second, literatures found that firm size is one of the firm value determinants. Firm size is a total reflection of an organization's assets. A manager of firm with greater assets is more flexible in using the existing firm assets. Large companies have easily access to capital market to obtain funds. Higher firm size is captured by investors as a positive signal and a good prospect so that firm size may influence firm value in a positive way. Third, debt monitoring is measured by ratio of total debt to total asset. A company that borrows funds from banks should sign a contract of debt agreement. The firm managers must run the company efficiently and effectively to avoid the violation of the debt agreement contract. Companies with high debt ratio receive additional supervision from banks. Thus, debt monitoring tends to have a positive impact on firm value.

However, past studies noted that the influence of these three factors on corporate value is still inconsistent. This paper examines the effect of three factors mentioned above on firm value in both situations: high vs. low earnings management. Earnings management practices may lead to a decrease in shareholder confidence against firm management. Therefore, the objective of this research is to examine the moderating effect of earnings management practices on the relationship between firm performance, firm size, debt monitoring and firm value. 


\section{REVIEW OF LITERATURE AND HYPOTHESIS DEVELOPMENT}

\section{A. Firm Performance and Firm Value}

Firm performance is the result of management achievement in financial terms. Firm performance may be stated as firm efficiency or the input and output ratio. In this study, firm performance is measured by Return on Asset (ROA) ratio. ROA measures a company's ability to efficiently manage its assets to generate profits or returns for shareholders. The financial performance of the company depends on how the management manages the company's finances and conducts the company's activities well; therefore the company's management is required to improve the ability to manage the company so as to maximize the value of the company.

Past studies found that firm value is determined positively by the earnings power of the company's assets. It indicates that the more earning power, the more efficient asset turnover and or the higher the profit margin obtained by the company. Firm performance has an impact on increasing the firm value [5]. ROA as a proxy for firm performance has a significant positive effect on stock returns one period ahead. Therefore, this study argues that firm performance (such as ROA) influence the firm value. Based on the above explanation, this research proposes the following hypothesis:

\section{H1: Firm Performance has a positive effect on Firm Value.}

\section{B. Firm Size and Firm Value}

Firm size is one of the variables considered in determining the value of the firm. Past studies measure the variable firm size in several ways such as the natural logarithm of total assets of company. The larger the firm size means that the company's assets are getting bigger and the funds required by the company to maintain its operational activities are also getting bigger. Firm size may describe that the company is experiencing good growth so that have a positive impact on the value of the company.

The larger the firm size will affect management decision in determining what funding will be used by the company so that funding decisions can optimize the value of the company. Past studies found that firm size influences the value of the company [6].

Research conducted by Gill and Obradovich [7] states that firm size has a significant positive effect on the value of a company. The statement is also in line with past research which states that firm size has a significant positive effect on firm value [8].

Based on the above explanation, this research proposes the following hypothesis:

\section{H2: Firm Size affects the firm's value.}

\section{Debt Monitoring and Firm Value}

Another factor that can affect the value of the company is Debt Monitoring. Debt Monitoring is measured with Leverage. Leverage is a funding policy related to the company's decision to finance the company. Companies that use debt have liabilities on interest expense and principal cost of loans. The use of debt (external financing) has a considerable risk of non- payment of debt, so the use of debt should pay attention to the company's ability to generate profits. One view indicates that the greater the debt the higher the risk the company cannot pay the installment of interest and principal of the debt. Management should pay attention to the use of debt, because this situation could have an impact on the value of the company [7].

However, companies with high debt will get additional supervision from banks. The companies must sign a contract of debt agreement. The companies will have an incentive to run the company efficiently and effectively in order to avoid breach of the debt agreement contract. This can give a positive signal to shareholders that the company is run for the benefit of shareholders and the value of the company. This situation is supported by past findings. There are several past studies find that debt monitoring influence firm value in a positive way. $[7,8]$. Based on the above explanation, this research proposes the following hypothesis:

\section{H3: Debt Monitoring positively affects Firm Value.}

\section{Growth and Firm Value}

Firm growth is the company's ability to increase its annual income higher than the industry average over a sustained period. In this study, company growth was measured by Price to Earnings Ratio (PER). PER illustrates the desire of investors to pay each rupiah on the earnings of the company. Companies that experienced high growth in generating profits showed substantial funding to finance corporate growth. Sometimes, the company limits the amount of dividends distributed, to hold the company's internal funds in investment activities. From the investor side, the company's growth shows positive signals and good developments as a company's growth and return on investment have a beneficial impact.

The higher demand from investors on the stock will affect the stock price and will increase the value of the company. So the higher the company's growth will be the higher the value of the company. Previous research found the result that company growth have significant effect and have positive relation to company value [2,3].

Based on the above explanation, this research proposes the following hypothesis:

\section{H4: Growth positively affects Firm Value}

\section{E. Earnings Management and Firm Value}

According to Scott [9], earnings management is a management action to choose accounting policies with certain standards to achieve certain profit targets, with the aim of maximizing the welfare of management and/or corporate value. Earnings management is influenced by the conflict of interest between the principal and the agent arising as each party seeks to achieve or consider the desired level of prosperity. Misleading reported earnings can result in poor quality of enterprise performance information, which may result in a decline in future corporate value.

Several previous studies have examined the effect of earnings management on firm values and they found that earnings management had a significant negative impact on firm 
value. The low quality of earnings information may result in incorrect investment decision making by users of financial statements such as investors and creditors and impose corporate value $[10,11]$.

Based on the above explanation, this research proposes the following hypothesis:

\section{H5: Earnings Management negatively affects Firm Value.}

\section{F. The Moderation Role of Earning Management}

Earnings management is an opportunistic behavior that occurs when managers use their discretionary financial reporting that may alter financial statements to mislead corporate stakeholders [12]. This opportunistic behavior is seen as implied management fraud in financial statements [13]. The manipulation practice known as earnings management may be done through income decreasing, income smoothing and income increasing. This manipulation is done by recognizing future earnings into current profits or vice versa, or managers shifting current costs into future costs or vice versa. Thus, revenues in the corresponding period will be reported higher or lower [14].

While some companies are motivated to do earnings management to give a positive signal about the future prospect of the company, most companies engage in earnings management practices to conceal the actual information of earnings. The management is worried about the market's negative reaction to information about low profit or losses. However, this positive signal in the long run cannot be maintained by management, which is reflected in the decline in performance reported by the company. Earnings management by management shows a good short-term performance of a company but will potentially decrease the value of the company. This is because the actions taken by management to improve the income of the current year will negatively impact future cash flows [9].

In situations where there is a high earnings management practice in the company, the positive influence of corporate performance, firm size, debt monitoring and growth on firm value is getting weaker. Conversely, in the case of low earnings management practices in the company, the positive influence of corporate performance, firm size, debt monitoring and growth of firm value is getting stronger. Based on the above explanation, this research proposes the following hypothesis:

H6: Earning management moderates the effect of firm performance, firm size, debt monitoring and growth on firm value.

\section{METHODOLOGY}

\section{A. Population and Sample}

The research population is a manufacturing company listed on Indonesia Stock Exchange during the period of 2014-2016. The research sample was taken by purposive sampling method based on this research criterion, see TABLE I. The study population and sample were taken from www.idx.com website in the form of annual financial report.

\begin{tabular}{|l|c|}
\hline \multicolumn{2}{|c|}{ Firm Year Observation } \\
\hline $\begin{array}{l}\text { Manufacturing firms listing on the Indonesia Stock } \\
\text { Exchange for the period 2014 and 2016 }\end{array}$ & 336 \\
\hline Firm with inaccessible annual report & 11 \\
\hline Firm with incomplete data & 57 \\
\hline Final Observation & 268 \\
\hline
\end{tabular}

B. Variables Operationalization

TABLE II. VARIABLE DEFINITION AND OPERATIONALIZATION

\begin{tabular}{|l|l|}
\hline \multicolumn{2}{|c|}{ Variable Definition and Operationalization } \\
\hline Dependent variable & \\
\hline FV Firm value & Tobin Q \\
\hline Moderating variable & \\
\hline EM $\quad$ Earnings management & Discretionary accruals \\
\hline Independent variable & \\
\hline FP $\quad$ Firm performance & ROA = Net income divided by the \\
\hline SIZE $\quad$ Firm size & Ln of total asset \\
\hline DM $\quad$ Debt monitoring & Leverage = Debt to total asset ratio \\
\hline PER $\quad$ Growth & Price earning ratio \\
\hline
\end{tabular}

The research examines the relationship between independent variables (such as firm performance, firm size, debt monitoring, and growth) on dependent variable (such as firm value); that is moderated by the earnings management variable. Operational definitions and measurements of research variables are shown in TABLE II.

\section{Research Model}

This study builds a regression model where firm performance, firm size, debt monitoring, growth, and earnings management are used as independent variables. Firm value used in this model as dependent variable. The research regression model is shown in Equation 1 below:

$\mathrm{FV}=\alpha+\beta 1 * \mathrm{FP}+\beta 2 * \mathrm{SIZE}+\beta 3 * \mathrm{DM}+\beta 4 * \mathrm{PER}+\beta 5^{*} \mathrm{EM}+\mathrm{e}$

To prove the role of moderating variable in the relationship between independent variables and dependent variable, this study uses a residual test. A residual test consists of two steps of regression models. In the first step, this study examines the effect of performance, firm size; debt monitoring and growth on earnings management (see Equation 2). The second step, this study tests the effect of firm value on the absolute value of the residual value of regression in Equation 2, please see Equation 3.

$$
\begin{aligned}
& \mathrm{EM}=\alpha+\beta 1 * \mathrm{FP}+\beta 2 * \mathrm{SIZE}+\beta 3 * \mathrm{DM}+\beta 4 * \mathrm{PER}+\varepsilon \\
& |\varepsilon|=\alpha+\beta 1 * \mathrm{FV}
\end{aligned}
$$

TABLE I. SAMPLE DESCRIPTION 


\section{RESULTS}

\section{A. Descriptive Statistic}

Descriptive statistics provide a general description of the research object to provide a preliminary overview of the research problem. Descriptive statistics of all research variables can be seen in TABLE III below.

TABLE III. DESCRIPTIVE STATISTICS

\begin{tabular}{|l|r|r|r|r|r|}
\hline & \multicolumn{1}{|c|}{$\mathbf{N}$} & \multicolumn{1}{c|}{ Min } & \multicolumn{1}{c|}{ Max } & \multicolumn{1}{c|}{ Mean } & \multicolumn{1}{c|}{$\begin{array}{c}\text { Std. } \\
\text { Deviation }\end{array}$} \\
\hline $\begin{array}{l}\text { Firm } \\
\text { Performance }\end{array}$ & 268 & -0.291 & 0.707 & 0.054 & 0.131 \\
\hline Firm Size & 268 & 0.000 & 33.648 & 27.150 & 4.239 \\
\hline $\begin{array}{l}\text { Debt } \\
\text { Monitoring }\end{array}$ & 268 & 0.000 & 4.302 & 0.537 & 0.435 \\
\hline Growth & 268 & -2.040 & 7.592 & 2.483 & 1.406 \\
\hline $\begin{array}{l}\text { Earnings } \\
\text { Management }\end{array}$ & 268 & -77.662 & 1.061 & -0.358 & 5.039 \\
\hline Firm Value & 268 & 0.000 & 23.181 & 1.707 & 2.594 \\
\hline $\begin{array}{l}\text { Valid N } \\
\text { (listwise) }\end{array}$ & 268 & & & & \\
\hline
\end{tabular}

Based on TABLE III, the descriptive analysis of each variable in this study is as follows: Dependent variable (Firm Value) in this study obtained the highest value of 23,181 achieved by PT Panasia Indo Resources, Tbk (HDTX) and the lowest value of 0,000 obtained by some companies such as PT Sekawan Intipratama, Tbk (SIAP), PT Siwani Makmur, Tbk (SIMA), and PT Chandra Asri Petrochemical (TPIA). The mean score of firm value is 1.707 and the standard deviation is 2.594 .

The moderating variable in this research is earnings management. The average value of earnings management is 0.358 and it's the standard deviation is 5.039. The highest earnings management score was 1,061 achieved by PT Selamat Sempurna, Tbk (SMSM) and the lowest value is obtained by PT Lotte Chemical Titan Tbk (FPNI) at -77.662 score.

The variable of Growth has the maximum score of 7.592 achieved by PT Star Petrochem Tbk (STAR) and the lowest score of -2,040 was obtained by PT Indo Kordsa, Tbk (BRAM). The average of growth rate is 2.483 and the standard deviation is 1.46 .

The variable of debt monitoring shows the highest value of 4.302 achieved by PT Asia Pacific Fibers Tbk (POLY) and the lowest value is 0.000 obtained by several companies namely PT Tiga Pilar Sejahtera Food, Tbk (AISA), PT Sumi Indo Kabel, Tbk (IKBI), and PT Malindo Feedmill, Tbk (MAIN).. The average value of debt monitoring is 0.537 and the standard deviation is 0.435 .

Firm size shows the maximum value of 33,648 earned by PT Alkindo Naratama, Tbk (ALDO) and the minimum value of 0.000 obtained by several companies namely PT Sumi Indo Kabel, Tbk (IKBI) and PT Malindo Feedmill, Tbk (MAIN). The average value of firm size is 27.150 and the standard deviation is 4.239 .

Firm performance using the proxy of return of assets has the highest value of 0.707 achieved by PT Sat Nusapersada Tbk (PTSN) and the lowest value of -0.291 obtained by PT Asia
Pacific Fibers, Tbk (POLY). The average firm performance value is 0.054 and the standard deviation is 0.131 .

\section{B. Multicolonierity Test}

Multicolinearity test was done to see whether in the regression model found the existence of high correlation between independent variables. The data in this regression model can be said to be free of multicollinearity problem if the Tolerance value is $>0.1$ or equal, and the VIF value $<10$ (Ghozali, 2015). Multicollenearity test results can be seen in TABLE IV below.

TABLE IV shows the correlation value between independent variables. The highest correlation coefficient is between firm performance variable and firm value of 0.224 where the correlation coefficient is still below 0.8 (Gujarati, 2003). Thus it can be concluded that in this research model there is no multicollinearity problem.

TABLE IV. CORRELATION COEFFICIENT

\begin{tabular}{|c|c|c|c|c|c|c|}
\hline & FP & SIZE & DM & PER & EM & FV \\
\hline $\begin{array}{l}\text { Firm } \\
\text { Performance } \\
(\mathrm{FP})\end{array}$ & 1 & & & & & \\
\hline $\begin{array}{l}\text { Firm Size } \\
\text { (SIZE) }\end{array}$ & 0,021 & 1 & & & & \\
\hline $\begin{array}{l}\text { Debt } \\
\text { Monitoring } \\
\text { (DM) }\end{array}$ & $-0,259^{* * *}$ & 0,023 & 1 & & & \\
\hline $\begin{array}{l}\text { Growth } \\
\text { (PER) }\end{array}$ & $0,132^{* *}$ & $0,181^{* * *}$ & $-0,253^{* * *}$ & 1 & & \\
\hline $\begin{array}{l}\text { Earnings } \\
\text { Manage- } \\
\text { ment (EM) }\end{array}$ & 0,035 & $0,177^{* * *}$ & 0,006 & $-0,035$ & 1 & \\
\hline $\begin{array}{l}\text { Firm Value } \\
(\mathrm{FV})\end{array}$ & $0,224^{* * *}$ & $0,177^{* * *}$ & 0,088 & $0,153^{* *}$ & 0,032 & 1 \\
\hline
\end{tabular}

\section{Partial Test ( $t$ test)}

Partial test (t test) is done to see how strong the influence of each independent variable (such as firm performance, firm size, debt monitoring, growth, and earnings management) on dependent variable (firm value). The requirements of the hypothesis to be tested are as follows:

a. If $\mathrm{t}$ arithmetic $<\mathrm{t}$ table, or the probability greater than significance level (sig.> 0, 05), it means that in partially there is no the effect of independent variable on dependent variable.

b. If $\mathrm{t}$ arithmetic $>\mathrm{t}$ table, or probability smaller than the level of significance (sig. <0.05) means that in partially, the independent variables affect the dependent variable. 
TABLE V. REsUlt OF T-Test

Coefficients $^{\mathrm{a}}$

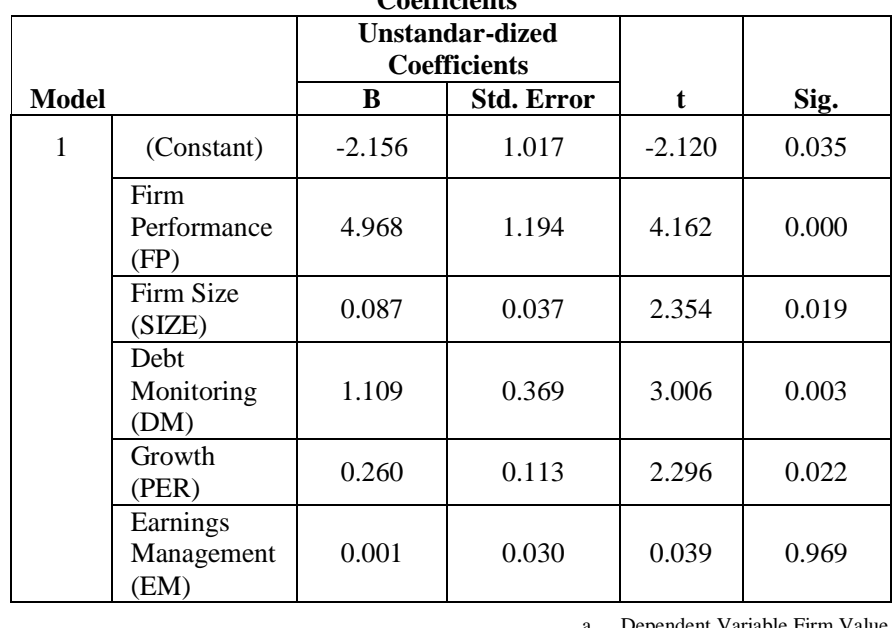

Based on TABLE V above, this study shows the influence of each independent variable to the dependent variable of this study. There are four variables that have a significance value such as firm performance, firm size, debt monitoring, and growth. Firm performance, firm size, debt monitoring, and partial growth have positive and significant effect on firm value. However, this study does not find the effect of earnings management on firm value.

\section{Simultaneous Test (F Test)}

The simultaneous test (F Test) is done to see how significant the influence of all independent variables (such as firm performance, firm size, debt monitoring, growth, and earnings management) on the dependent variable (firm value) simultaneously. The results of $F$ test are shown in TABLE VI below.

TABLE VI. RESUlt OF F TEST

\begin{tabular}{|l|r|r|c|c|c|}
\multicolumn{7}{|c|}{ ANOVA $^{\mathrm{a}}$} \\
Model & $\begin{array}{c}\text { Sum of } \\
\text { Squares }\end{array}$ & \multicolumn{1}{c|}{ Df } & $\begin{array}{c}\text { Mean } \\
\text { Squar } \\
\text { e }\end{array}$ & F & Sig. \\
\hline 1Regression & 214.323 & 5 & 42.865 & 7.101 & $0.000^{\mathrm{b}}$ \\
Residual & 1581.595 & 262 & 6.037 & & \\
Total & 1795.917 & 267 & & & \\
\hline
\end{tabular}

a. Dependent Variable: Firm Value.

b. Predictors: (Constant), Earnings Management, Debt Monitoring, Firm Size, Firm Performance, Growth.

Based on TABLE VI above, this study shows that F test is significant. It means that firm performance, firm size, debt monitoring, growth, and earnings management influence firm value, simultaneously.

\section{E. Residual Test}

The residual test is performed to see the lack of fit resulting from the deviation of the linear relationship between the independent variables of a model (ghozali, 2006: 171). Residual test results can be seen in TABLE VII below.
TABLE VII. RESUlt OF RESIDUAL TEST

\begin{tabular}{|c|c|c|c|c|c|}
\hline \multirow{2}{*}{ Model } & \multicolumn{2}{|c|}{$\begin{array}{c}\text { Unstandardized } \\
\text { Coefficients }\end{array}$} & & \multirow{2}{*}{ Sig. } \\
\cline { 2 - 4 } & $\mathbf{B}$ & \multicolumn{1}{|c|}{ Std. Error } & t & Sig. \\
\hline \multirow{2}{*}{1} & (Constant) & 1.152 & 0.354 & 3.252 & 0.001 \\
\cline { 2 - 4 } & Firm Value & -0.077 & 0.114 & -0.670 & 0.504 \\
\hline
\end{tabular}

a. Dependent Variable: the absolute value of Residual Score

TABLE VII shows that the effect of firm value on the absolute value of the residual score is not significant. So it can be concluded that earnings management is not a moderating variable in the relationship between firm performance, firm size and debt monitoring.

\section{RESULTS}

This paper examines the effects of firm performance, firm size, debt monitoring and growth on firm value. This study also tests the moderating role of earnings management in the relationship between firm performance, firm size, debt monitoring, growth and firm value. The results of this paper suggest that firm performance, firm size, debt monitoring, and growth have a positive and significant effect on firm value. It shows that high firm performance, large firm size, effective debt monitoring and high firm growth are important factors to increase the firm value. However, this study does not find the strong evidence of the moderating role of earnings management. This study noted that future study needs to search for a better measure of earnings management.

\section{REFERENCES}

[1] H. Chung, W.Q Judge, and Y. Li, "Voluntary disclosure, excess executive compensation, and firm value". Journal of Corporate Finance, vol.32, 2015, pp. 64-90.

[2] S. Hermuningsih, "Profitability, growth opportunity, capital structure and the firm value," Bulletin of Monetary, Economics and Banking, 2013, pp. 116-136.

[3] Moeljadi and T.S. Supriyati,. "Factors affecting firm value : Theoretical study on public manufacturing firms in Indonesia," South Asia Journal of Contemporary Business, Economics and Law, vol 5, 2014, pp. 6-15.

[4] A. Bhardwaj, and N. Dhansoia, "Financial leverage and firm value: A study of manufacturing sector firms," IOSR Journal of Business and Management, 2015, pp. 75-81.

[5] O. Kodongo, L. Maina, and M.T. Mokoteli, "Capital structure, profitability and firm value: Panel evidence of listed firms in Kenya," 2014, Munich Personal RePEc Archive. No 57116.

[6] A. Rasyid, Mahfudnurnajamuddin, M. Mas'sud, M. Su'un, "Effect of ownership structure, company size and profitability on dividend policy and manufacturing company's value in Indonesia Stock Exchange," Australian Journal of Basic and Applied Sciences, vol. 9(20), 2015, pp. 618-624.

[7] A. Gill, and J. D. Obradovich, "The impact of corporate governance and financial leverage on the value of American firms," International Research Journal of Finance and Economics, vol. 91, 2012.

[8] M.C. Cheng and Z.C. Tzeng. "The effect of leverage on firm value and how the firm financial quality influence on this effect," World Journal of Management, vol. 3(2), 2011, pp. 30-53.

[9] W.R. Scott, "Financial Accounting theory", 4th Edition. Canada Inc : Pearson Education, 2006.

[10] R. Bukit and T.M. Iskandar, "Surplus cash flow, earnings management and audit committee," International Journal of Economics and Management vol. 3(1), 2009, pp. 204-223. 
[11] R. Bukit and F.N. Nasution,'Employee diff, free cash flow, corporate governance and earnings management," Procedia Social and Behavioral Sciences vol. 211, 2015, pp. 585-594.

[12] P.M. Heally and J.M. Wahlen, "A review of the earning management literature and its implication for standard setting." Accounting Horizon, 2000, pp. 365-383.
[13] M.D. Beneish, "Earnings management: A perspective," Managerial Finacial, vol. 27 (12), 2001, pp. 3-17.

[14] S. Espenlaub, "Discussion of the life cycle of initial public offering firms," Journal of Business Finance \& Accounting, vol. 26 (9-10), 1999, pp. 1309-1317. 